sentative from each of the schools. At this stage the Native Authority, the Bekwaihene and his Councillors, began to take an interest and, in addition to appointing two members to the Committee, voted a sum of $£ 72$ towards the expenses of the expanded scheme. It was not long before all schoolboys in Bekwai from Standard I to Standard VII were devoting one day a week to art and craft work. Early in 1943 it was found possible to erect suitable buildings on a more central site and Bekwai United Schools Arts and Crafts Centre came into being under the charge of one of Mr. Meyerowitz's former pupils. 'The Centre, although still in an experimental stage, has already attracted widespread interest, and local enthusiasm has been such that the Committee has had some difficulty in controlling what constantly tends to become a too rapid expansion. Among the crafts taught are traditional Ashanti weaving (a broad loom has just been introduced), basket-making, mat-weaving, wood-carving, brick-making, and pottery. Associated with the Achimotatrained Supervisor are four craft-instructors whose knowledge of their own craft it is hoped to enhance without sactificing that natural grace of design for which the West African traditional crafts are justly reputed.

This Centre is believed to be the only one of its kind in West Africa where the pupils of four different denominational schools are taught together. Its finances are controlled by the Education Committee and the member-schools have adjusted their individual time-tables to fit in with the scheme. At the end of 1943 the Committee and the Bekwai Native Authority each offered a bursary tenable at Achimota to a suitable pupil of the Centre who wished to be trained as an apprentice in one of the craft-industries.

In addition to directing this experiment, the Bekwai Education Committee has started a Domestic Science Centre for the schoolgirls in the town and has investigated various local educational problems. When it is appreciated that the Committee had no official standing whatsoever and relied for its effect entirely on the voluntary co-operation of the Native Authority and the representatives of four such divergent Christian denominations as Roman Catholic, Anglican, Methodist, and Seventh Day Adventist, its initial success is surely a happy augury for the future of education in Africa.

\title{
A Musical Play for Africans
}

IN Chief Above and Chief Below, Hugh Tracey, of Broadcast House, Durban, has written a musical play. based on an old Zulu legend discovered by K. E. Masinga when searching for material suitable for broadcasting. The legend is narrated in verse at the beginning of the play, and this story of the Chief's daughter who was lured to the underworld to become the bride of the Chief Below, and of the famine and sorrow which overwhelmed her land till she was found and brought back by her old nurse, and 'then all the people rejoiced and singing they ploughed their fields', will suggest to the European reader many parallels with the myth of Demeter and Persephone.

The text of the play, which is published by Shuter and Shooter, Pietermaritzburg, with six full-page illustrations by E. F. Watkins, is given in Zulu and in English. We propose to publish a review in the next issue of Africa.

\section{'Revue des Sciences Médicales, Pharmaceutiques et Vétérinaires de L'Afrique Frangaise Libre'}

THE medical, entomological, and veterinary services of the French Colonial territories in Africa have, since 1942, issued a Revue des Sciences Médicales, Pharmaceutiques et Veterinaires de l'Afrique Frangaise Libre, which is published by the Imprimerie du Gouvernement Général, Brazzaville. The papers in the first two volumes cover a wide field, including clinical reports on some noteworthy medical cases and more general surveys of medical conditions in various territories. Among the latter is a regional account of the methods and 